J. AMER. SOC. HorT. SCI. 118(6):766-770. 1993.

\title{
Pungency and Sugars of Short-day Onions as Affected by Sulfur Nutrition
}

\author{
W.M. Randle and M.L. Bussard \\ Department of Horticulture, University of Georgia, Athens, GA 30602-7273 \\ Additional index words. Allium cepa, pyruvic acid, sucrose, fructose, glucose, fructans, flavor, cultivars
}

\begin{abstract}
Sixteen short-day onion (Allium cepa $\mathbf{L}$.) cultivars with high $\left(4.0\right.$ meq·liter $\left.{ }^{-1}\right)$ and low $S\left(0.1\right.$ meq-liter $\left.^{-1}\right)$ fertility were evaluated for several characteristics associated with bulb flavor. Sulfur levels interacted with cultivars in influencing bulb pungency and concentrations of $S$ and individual sugars, except for fructose. Enzymatically formed pyruvic acid correlated poorly with bulb $S$ concentration, which suggests differential partitioning of $S$ into flavor and nonflavor compounds among cultivars. Bulb percent dry weight correlated negatively with bulb $S$ concentration. Since poor correlations were found between enzymatically formed pyruvic acid and water-soluble carbohydrates, we postulate that pungency and sweetness function independently in bulbs of fresh-market short-day onion cultivars.
\end{abstract}

Flavor in onions (Allium cepa) is dominated by up to 80 unique $\mathrm{S}$ compounds that are characteristic of the genus Allium and several water-soluble carbohydrates (WSC) (Lancaster and Boland, 1990). Flavor intensity is determined by the genetics of an individual cultivar and the environment in which the cultivar is grown. Genetic variation has been demonstrated within onion for individual and total sugars (Bajaj et al., 1980; Darbyshire and Henry, 1979; Randle, 1992a), pungency (Bajaj et al., 1980; Lancaster et al., 1988; Randle, 1992b; Schwimmer and Weston, 1961), and a variety of volatile S compounds (Freeman and Whenham, 1975; Whitaker, 1976). Differences in flavor intensity between locations and years have been reported for individual cultivars (Bedford, 1984; Lancaster et al., 1988; Platenius and Knott, 1941). Specific environmental factors influencing flavor intensity are temperature (Platenius and Knott, 1941), irrigation (Freeman and Mossadeghi, 1973), N-form (Gamiely et al., 1991) and S fertility (Balasubramonian et al., 1978; Freeman and Mossadeghi, 1970; Paterson, 1979; Randle, 1992b; Smittle, 1984). Lancaster and Boland (1990) and Whitaker (1976) have reviewed the metabolism of S compounds in onion and the subsequent breakdown products that remain when S-alk(en)yl cysteine sulfoxide flavor precursors are acted on by the enzyme alliinase.

Much also is known of the composition, synthesis, distribution, cultivar and species differences, and contribution to sweetness of WSC in onions (Darbyshire and Steer, 1990). However, the association between $\mathrm{S}$ compounds and WSC has received little attention. The S compounds normally overpowerthe WSC during organoleptic assessment. In general, as the percent of dry weight increases in onion cultivars, pungency increases (Jones and Mann, 1963), although exceptions have been reported (Randle, 1992b). For sweetness in onions to be tasted, the dominant effect of pungency must be minimized. Pungency can be minimized in commercial production by growing low-pungency cultivars in a low-S environment (Vavrina and Granberry, 1988). As production and consumption of sweet, low-pungency onions increases (Aylsworth, 1991), a greater understanding is needed of how pungency and WSC interact in onions, especially in response to different $\mathrm{S}$ fertility levels. The objectives of this research were to evaluate low-pungency, short-day onion cultivars for pungency and WSC when grown with high and low S fertility, and to determine the association between the two classes of flavor components.

Received for publication 17 July 1992. Accepted for publication 1 Feb. 1993. The cost of publishing this paper was defrayed in part by the payment of page charges. Under postal regulations, this paper therefore must be hereby marked advertisement solely to indicate this fact.

\section{Materials and Methods}

Sixteen short-day, low-pungency onion cultivars were obtained from six commercial seed companies: 'Primavera' and 'Savannah Sweet' from PetoSeed, Saticoy, Calif.; 'Gran Prix', 'Willmette Sweet', 'Special 38', and 'Henry's Special' from SunSeed, Hollister, Calif.; 'Z238' and 'Z235' from Neuman Seed, El Centro, Calif.; 'Maestro' and 'Granex 429' from Asgrow, Kalamazoo, Mich.; 'Rio Rajirad', 'Rio Bravo', 'Sweet Vidalia', 'Rio Ringo', and 'Sweet Georgia' from Rio Colorado Seeds, Yuma, Ariz.; and 'SweetTex' from Ferry Morse Seed Co., Modesto, Calif. Seeds of each entry were sown in Fafard no. 3 artificial medium (Fafard, Anderson, S.C.) in plastic trays on 1 Dec. 1990. Plants were grown under natural photoperiods and light intensities in a greenhouse. Night and day temperatures were set at 16 and 28C, respectively. Seedlings were fertilized twice with half-strength Hoagland and Arnon solution (Hoagland and Arnon, 1950) before being transplanted to 0.75-liter pots containing the same medium on 1 Feb. 1991. A split-plot design with three replications and five pots per replication was used. Sulfur fertility levels were the main plots and cultivars the subplots. Full-strength Hoagland's solution was modified to contain 4.0 (high level) or 0.1 (low level) meq S/liter. The low concentration was selected because growth of "White Lisbon' onions was reduced by up to $50 \%$ with $<0.1$ meq S/liter (Freeman and Mossadeghi, 1970). The high level was selected because it resulted in pungency levels similar to those in field-grown onions when fertilized with S-containing fertilizers. Sulfuric acid was the $\mathrm{S}$ source. Magnesium chloride was substituted for magnesium sulfate in the modified solution. Solution $\mathrm{pH}$ was adjusted to 6.5 with $\mathrm{NaOH}$. Plants were watered twice each week with $\approx 100$ $\mathrm{ml}$ of nutrient solution/pot and supplemented with tap water as needed. Tap water $(\mathrm{pH}$ 6.2) had $<0.05$ meq S/liter. The growth medium was leached once a week.

Bulbs were considered harvestable when the foliage had lodged on four of five plants in a replication. Irrigation was then withheld and the plants were allowed to dry for 7 days before all five bulbs were harvested. A five-bulb sample from three replications was sufficient to detect desired differences (Randle, 1992c). The earliest-maturing cultivar was harvested 1 May 1991, while the

Abbreviations: BPY, background pyruvic acid concentration; DM, dry matter; EPY, enzymatically formed pyruvic acid concentration; FT, total fructan concentration; FW, fresh weight; SSC, soluble solids concentration; TPY, total pyruvic acid concentration; TRS, total reducing sugars; WSC, water-soluble carbohydrates. 
latest-maturing cultivar was harvested 15 June 1991. Foliage and roots were severed at this time. The bulbs were cured in paper bags at 28/16C (day/night) for 7 days and stored at 22C for 30 days before analysis.

Sucrose, fructose, glucose, and total fructan concentrations were determined by the method of Randle (1992a). Sucrose and total reducing sugar concentrations were determined before and after invertase digestion using p-hydroxybenzoic acid hydrazide for spectrophotometric evaluation at $415 \mathrm{~nm}$. Total fructose concentration (free fructose, fructose in sucrose, and fructose in fructans) was determined using 2-thiobarbituric acid for spectrophotometric evaluation at $430 \mathrm{~nm}$. Total fructan concentration (FT) was obtained by first removing the interference of free fructose and fructose from sucrose with an invertase digestion followed by $\mathrm{NaOH}$ and heating to $100 \mathrm{C}$. Total fructan concentrations then were determined using 2-thiobarbituric acid as described above. Concentrations were calculated as follows: sucrose $=$ total reducing sugars $($ TRS) with invertase - TRS without invertase; fructose = total fructose - fructose from sucrose fructose from fructans; glucose $=$ TRS without invertase - calculated fructose. Total WSC concentration was the sum of the concentrations of sucrose, glucose, fructose, and total fructans. Soluble solids concentration (SSC) was determined with a Kernco hand-held refractometer (Kernco, Tokyo) on the combined expressed juice from the five-bulb sample. Bulb tissue was dried at $70 \mathrm{C}$ for $48 \mathrm{~h}$ in a forced air oven before measuring percent dry matter (DM) .

Enzymatically formed pyruvic acid concentration (EPY) was determined using the modified method of Schwimmer and Weston (1961). We ground bulb tissue samples in a Waring blender, incubated the samples with 2,4-dinitrophenylhydrazine, and read the absorbance at $420 \mathrm{~nm}$ on a spectrophotometer for total pyruvic acid concentration (TPY). Background concentrations of pyruvic acid (BPY) were determined by grinding bulb tissue samples in $5 \%$ trichloroacetic acid to stop the enzymatic cleavage of the flavor precursor molecules, and then continuing the procedure. Background pyruvic acid concentration was subtracted from TPY to give EPY as a measure of bulb pungency (Schwimmer and Guadagni, 1962). Pyruvic acid concentrations were determined against a sodium pyruvate standard curve. Bulb total $\mathrm{S}$ concentration was determined using the procedures of Jones and Isaac (1972). Ground bulb tissue, magnesium oxide, and iron accelerator were placed in a muffle furnace at 500C for $1 \mathrm{~h}$, combusted with iron and tin accelerators on a Leco sulfur analyzer (Leco Laboratory Equipment Corp., St. Joseph, Mich.); measurements were made against a standard curve. A ratio was calculated between bulb EPY and $\mathrm{S}$ concentrations.

Data were tested by analysis of variance (ANOVA) using SAS procedures (SAS, Cary, N.C.), with cultivar means separated by least significant difference (LSD) of 0.05 within and between S fertility levels. A correlation matrix for cultivars within $S$ fertility was calculated for all variables tested. To test differences in rank order among the cultivars at the two S fertility levels, Spearman's rank correlations were calculated (Steel and Torrie, 1980).

\section{Results and Discussion}

Growth was typical of field-grown plants, although top growth and bulbs were slightly smaller due to pot restrictions. Sulfur fertility level exerted highly significant effects $(P \leq 0.01)$ on all variables except fructose concentration. Generally, high $\mathrm{S}$ fertility resulted in higher values for the variables than low $S$ fertility

Table 1. Bulb concentrations of total pyruvic acid (TPY), background pyruvic acid (BPY), enzymatically formed pyruvic acid (EPY), and total sulfur (S); EPY to $S$ ratio $(E: S)$; dry matter percentage (DM); and DM : S ratio of 16 short-day onion cultivars grown with high (4.0 meq-liter $\left.{ }^{-1}\right)$ and low $\mathrm{S}\left(0.1 \mathrm{meq} \cdot\right.$ liter $\left.^{-1}\right)$ fertility.

\begin{tabular}{|c|c|c|c|c|c|c|c|c|c|c|c|c|c|c|}
\hline \multirow[b]{3}{*}{ Cultivar } & \multicolumn{2}{|c|}{ TPY } & \multicolumn{2}{|c|}{$\begin{array}{c}\text { BPY } \\
(\mathrm{mol} / \mathrm{g} \text { fresh wt) }\end{array}$} & \multicolumn{2}{|c|}{ EPY } & \multirow{2}{*}{\multicolumn{2}{|c|}{$\begin{array}{c}\mathrm{S} \\
(\% \text { dry wt) }\end{array}$}} & \multirow{2}{*}{\multicolumn{2}{|c|}{$\mathrm{E}: \mathrm{S}$}} & \multicolumn{2}{|c|}{$\begin{array}{c}\text { DM } \\
(\% \text { fresh wt) }\end{array}$} & \multicolumn{2}{|c|}{$\mathrm{DM}: \mathrm{S}$} \\
\hline & \multirow[b]{2}{*}{ High } & \multirow[b]{2}{*}{ Low } & \multirow[b]{2}{*}{ High } & \multirow[b]{2}{*}{ Low } & \multirow[b]{2}{*}{ High } & \multirow[b]{2}{*}{ Low } & & & & & & & & \\
\hline & & & & & & & High & Low & High & Low & High & Low & High & Low \\
\hline Gran Prix & 4.9 & 3.9 & 0.9 & 0.3 & 4.0 & 3.6 & 0.68 & 0.31 & 5.9 & 11.6 & 7.5 & 7.2 & 11.0 & 23.2 \\
\hline Granex 429 & 4.7 & 3.2 & 0.3 & 0.4 & 4.4 & 2.8 & 0.48 & 0.21 & 9.2 & 13.3 & 7.9 & 7.8 & 16.5 & 37.1 \\
\hline Henry's Special & 5.0 & 3.0 & 0.5 & 0.5 & 4.5 & 2.5 & 0.58 & 0.22 & 7.7 & 11.4 & 8.2 & 8.2 & 14.1 & 37.3 \\
\hline Maestro & 6.2 & 3.3 & 0.6 & 0.6 & 5.6 & 2.7 & 0.59 & 0.19 & 9.5 & 14.2 & 9.1 & 8.9 & 15.4 & 46.2 \\
\hline Primavera & 5.0 & 3.2 & 0.7 & 0.6 & 4.3 & 2.6 & 0.66 & 0.36 & 6.5 & 7.2 & 5.6 & 6.4 & 8.5 & 17.8 \\
\hline Rio Bravo & 4.8 & 3.8 & 0.1 & 0.3 & 4.7 & 3.5 & 0.63 & 0.26 & 7.5 & 13.5 & 8.1 & 8.6 & 12.9 & 33.1 \\
\hline Rio Rajirad & 5.4 & 3.3 & 0.6 & 0.5 & 4.8 & 2.8 & 0.47 & 0.18 & 10.2 & 15.6 & 9.1 & 8.1 & 19.4 & 45.0 \\
\hline Rio Ringo & 6.0 & 2.5 & 1.0 & 0.3 & 5.0 & 2.2 & 0.53 & 0.20 & 9.4 & 11.0 & 7.8 & 7.2 & 14.7 & 36.0 \\
\hline Savannah Sweet & 4.5 & 3.8 & 1.0 & 0.8 & 3.5 & 3.0 & 0.62 & 0.37 & 5.6 & 8.1 & 6.8 & 6.7 & 11.0 & 18.1 \\
\hline Special 38 & 6.1 & 3.6 & 0.7 & 0.2 & 5.4 & 3.4 & 0.55 & 0.28 & 9.8 & 12.1 & 6.6 & 7.8 & 12.0 & 27.9 \\
\hline Sweet Georgia & 4.2 & 2.9 & 0.6 & 0.2 & 3.6 & 2.7 & 0.50 & 0.24 & 7.2 & 11.2 & 7.8 & 8.6 & 15.6 & 35.8 \\
\hline SweetTex & 6.5 & 3.9 & 1.0 & 1.1 & 5.5 & 2.8 & 0.58 & 0.14 & 9.5 & 20.0 & 7.1 & 8.4 & 12.2 & 60.0 \\
\hline Sweet Vidalia & 4.3 & 2.4 & 0.3 & 0.1 & 4.0 & 2.3 & 0.59 & 0.22 & 6.8 & 10.4 & 7.7 & 7.5 & 13.0 & 34.1 \\
\hline Willmette Sweet & -5.6 & 3.4 & 0.6 & 0.9 & 5.0 & 2.5 & 0.64 & 0.21 & 7.8 & 11.9 & 7.9 & 8.4 & 12.3 & 40.0 \\
\hline Z 235 & 5.2 & 3.6 & 0.7 & 0.6 & 4.5 & 3.0 & 0.58 & 0.24 & 7.8 & 12.5 & 8.1 & 7.9 & 14.0 & 32.9 \\
\hline Z 238 & 5.3 & 3.3 & 0.4 & 0.5 & 4.9 & 2.8 & 0.59 & 0.20 & 8.3 & 14.0 & 8.2 & 7.8 & 13.9 & 39.0 \\
\hline Mean & 5.2 & 3.3 & 0.6 & 0.5 & 4.6 & 2.8 & 0.58 & 0.24 & 8.0 & 12.4 & 7.8 & 7.7 & 13.5 & 35.2 \\
\hline $\operatorname{LSD}_{0.05}{ }^{2}$ & \multicolumn{2}{|c|}{0.767} & \multicolumn{2}{|c|}{0.3} & \multicolumn{2}{|c|}{0.3} & \multicolumn{2}{|c|}{0.05} & \multicolumn{2}{|c|}{0.7} & \multicolumn{2}{|c|}{0.4} & \multicolumn{2}{|c|}{1.0} \\
\hline $\operatorname{LSD}_{0.05}{ }^{y}$ & \multicolumn{2}{|c|}{0.3} & \multicolumn{2}{|c|}{0.767} & & & & & & & & & & 8 \\
\hline
\end{tabular}

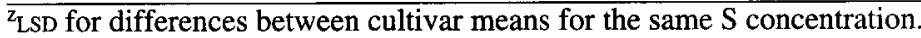

$\mathrm{y}_{\mathrm{LSD}}$ for differences between cultivar means for the different $\mathrm{S}$ concentrations. 
(Tables 1 and 2). Bulb EPY, carbohydrate, and S concentrations were within the range of those reported for field-grown (Paterson, 1979; Smittle, 1984) and greenhouse-grown (Balasubramonian et al., 1978; Randle, 1992a, 1992b) short-day onions in which S nutrition was varied.

Highly significant interactions $(P=0.01)$ were found between $S$ level and cultivar for all variables tested. Bulb EPY ranged from 5.6 ('Maestro') to $3.5 \mu \mathrm{mol} \cdot \mathrm{g}^{-1}$ fresh weight (FW) ('Savannah Sweet') with high S fertility and from 3.6 ('Gran Prix') to 2.2 ('Rio Ringo') with low S fertility (Table 1). Rank order of EPY changed significantly for the cultivars grown at the two $\mathrm{S}$ fertility levels [Spearmans rank correlation $(r s)=0.02^{\mathrm{NS}}$ ]. Bulb S varied from $0.68 \%$ ('Gran Prix') to $0.47 \%$ ('Rio Rajirad') with high S fertility and from $0.37 \%$ ('Savannah Sweet') to $0.14 \%$ ('SweetTex') with low $\mathrm{S}$ fertility (Table 1). This range was lower than that previously reported for onion germplasm of broad genetic background (Randle, 1992b). Spearmans rank correlation for bulb $S$ concentration between high and low $\mathrm{S}$ fertility was moderate $(r s=0.54)$ and significant. Bulb EPY : S concentration also was affected significantly by $S$ treatment (Table 1). The higher the ratio, the greater the proportion of total $\mathrm{S}$ available as flavor precursors in the biosynthetic pathway (Lancaster and Boland, 1990). In this pathway, the enzyme alliinase only acts on the S-alk(en)yl cysteine sulfoxide precursors and not on the flavor precursor intermediates to produce pyruvic acid as a product of enzymatic cleavage. Bulb EPY : S concentration ratios were lower with high than with low $\mathrm{S}$ fertility, suggesting that these cultivars were more efficient at assimilating $\mathrm{S}$ into the flavor precursors with low than with high $\mathrm{S}$ fertility. With high S, the bulb EPY : S concentration ratio ranged from 10.2 ('Rio Rajirad') to 5.6 ('Savannah Sweet'); with low S, 'SweetTex' (EPY $: S=20.0$ ) was very efficient in allocating $S$ to the flavor precursors, while 'Primavera' (7.2) and 'Savannah Sweet' (8.1) were much less efficient. Cultivars with a low EPY : S ratio, therefore, can be grown at higher $\mathrm{S}$ fertility and produce less pungent onions than cultivars with higher ratios. The correlation between bulb EPY and S concentration with high $S$ fertility was not significant (Table 3 ), but with low $\mathrm{S}$, the correlation was significant $(P \leq 0.01)$ but poor $(r=0.36)$. Poor correlation between bulb EPY and S concentration suggest differential partitioning of S into various flavor and nonflavor compounds in the sweet, mild, short-day onion cultivars tested.

Bulb DM as a percent of PW ranged from 9.1\% ('Maestro' and 'Rio Rajirad') to $5.6 \%$ ('Primavera') with high S fertility and from $8.9 \%$ ('Maestro') to $6.4 \%$ ('Primavera') with low S fertility (Table 1). Bulb SSC ranged from $8.0 \%$ ('Rio Rajirad') to $4.0 \%$ ('Primavera') with high S fertility and from $7.8 \%$ ('Rio Bravo') to $5.2 \%$ ('Primavera') with low S fertility (Table 2). The correlations between DM and SSC at high and low S fertility were moderate $(r$ $=0.53$ and 0.48 , respectively), and highly significant $(\mathrm{P} \leq 0.01$; Table 3). Spearmans rank correlation between high and low $\mathrm{S}$ fertility for DM was moderate $(r s=0.64)$ and highly significant, while for SSC, the correlation was poor $(r s=0.32)$, but significant $(P=0.05)$.

The correlation between bulb DM and $\mathrm{S}$ concentration with high $\mathrm{S}$ fertility was negative and poor $(r=-0.34)$, but significant $(P=0.05)$ (Table 3). Conversely, with low $\mathrm{S}$ fertility, the correlation between bulb DM and S concentration was negative, moderately high ( $r=-0.69)$, and significant. Interestingly, bulb DM was negatively correlated with bulb $\mathrm{S}$ concentration, especially with low $\mathrm{S}$ fertility. Onions devote much energy to metabolizing $\mathrm{S}$ compounds (Lancaster and Boland, 1990). In onions, there appears to be a balance between energy used in the synthesis of WSC vs. $\mathrm{S}$ compounds. Generally, cultivars that had higher $\mathrm{S}$ assimilation at low S fertility had lower DM accumulation in our study.

Table 2. Bulb concentrations of sucrose (SUC), fructose (FRU), glucose (GLU), total reducing sugars (TRS), total fructans (FT), total water-soluble carbohydrates (WSC), and soluble solids (SSC) of 16 short-day onion cultivars grown with high $\left(4.0 \mathrm{meq} \cdot 1\right.$ liter $\left.{ }^{-1}\right)$ and low $\mathrm{S}\left(0.1 \mathrm{meq}^{\left.-1 i t e \mathrm{r}^{-1}\right)}\right.$ fertility.

\begin{tabular}{|c|c|c|c|c|c|c|c|c|c|c|c|c|c|c|}
\hline \multirow[b]{3}{*}{ Cultivar } & \multicolumn{2}{|c|}{ SUC } & \multicolumn{2}{|c|}{ FRU } & \multirow{2}{*}{\multicolumn{2}{|c|}{$\begin{array}{c}\text { GLU } \\
\left(\mathrm{g} / 100 \mathrm{~g} \text { fresh } w t^{-1}\right)\end{array}$}} & \multicolumn{2}{|c|}{ TRS } & \multicolumn{2}{|c|}{ FT } & \multicolumn{2}{|c|}{ WSC } & \multicolumn{2}{|c|}{$\begin{array}{c}\text { SSC } \\
(\% \text { fresh wt) }\end{array}$} \\
\hline & & & & & & & \multicolumn{2}{|c|}{$S$ fertility } & \multirow[b]{2}{*}{ High } & \multirow[b]{2}{*}{ Low } & \multirow[b]{2}{*}{ High } & \multirow[b]{2}{*}{ Low } & \multirow[b]{2}{*}{ High } & \multirow[b]{2}{*}{ Low } \\
\hline & High & Low & High & Low & High & Low & High & Low & & & & & & \\
\hline Gran Prix & 1.2 & 1.5 & 2.2 & 1.5 & 2.2 & 1.3 & 4.4 & 2.8 & 0.2 & 0.3 & 5.8 & 4.6 & 6.0 & 5.4 \\
\hline Granex 429 & 0.2 & 2.6 & 2.2 & 1.6 & 2.1 & 1.7 & 4.3 & 3.3 & 0.2 & 0.2 & 4.7 & 6.1 & 5.0 & 7.2 \\
\hline Henry's Special & 1.9 & 1.5 & 2.2 & 1.7 & 2.3 & 2.5 & 4.5 & 4.2 & 0.4 & 0.3 & 6.8 & 6.0 & 7.6 & 6.2 \\
\hline Maestro & 1.3 & 2.1 & 1.5 & 1.9 & 2.2 & 2.4 & 3.7 & 4.3 & 0.3 & 0.6 & 5.3 & 7.0 & 6.6 & 7.6 \\
\hline Primavera & 0.4 & 0.9 & 1.3 & 1.7 & 1.9 & 1.7 & 3.2 & 3.4 & 0.1 & 0.2 & 3.7 & 4.5 & 4.0 & 5.2 \\
\hline Rio Bravo & 1.6 & 2.2 & 2.0 & 2.4 & 1.9 & 1.8 & 3.9 & 4.2 & 0.3 & 0.7 & 5.8 & 7.1 & 6.0 & 7.8 \\
\hline Rio Rajirad & 2.0 & 2.0 & 2.0 & 2.4 & 2.5 & 2.3 & 4.5 & 4.7 & 0.6 & 0.4 & 7.1 & 7.1 & 8.0 & 7.2 \\
\hline Rio Ringo & 1.5 & 1.2 & 2.1 & 1.8 & 2.6 & 1.7 & 4.7 & 3.5 & 0.2 & 0.1 & 6.4 & 4.8 & 7.0 & 5.6 \\
\hline Savannah Sweet & 1.3 & 1.1 & 2.0 & 2.2 & 1.5 & 2.0 & 3.5 & 4.2 & 0.4 & 0.2 & 5.2 & 5.5 & 6.0 & 5.6 \\
\hline Special 38 & 1.4 & 1.6 & 1.8 & 1.7 & 1.9 & 2.0 & 3.7 & 3.7 & 0.2 & 0.2 & 5.3 & 5.5 & 6.0 & 6.4 \\
\hline Sweet Georgia & 1.6 & 2.0 & 2.3 & 2.3 & 2.0 & 1.6 & 4.3 & 3.9 & 0.3 & 0.3 & 6.2 & 6.2 & 6.2 & 6.4 \\
\hline SweetTex & 1.0 & 1.8 & 2.0 & 1.7 & 2.0 & 2.1 & 4.0 & 3.8 & 0.2 & 0.3 & 5.2 & 5.9 & 5.8 & 6.2 \\
\hline Sweet Vidalia & 1.7 & 1.4 & 2.3 & 2.2 & 2.0 & 2.0 & 4.3 & 4.2 & 0.2 & 0.1 & 6.2 & 5.7 & 6.2 & 6.2 \\
\hline Willmette Sweet_- & 1.1 & 1.5 & 2.1 & 2.2 & 2.6 & 2.8 & 4.7 & 5.0 & 0.2 & 0.2 & 6.0 & 6.7 & 6.2 & 7.0 \\
\hline $\mathrm{Z} 235$ & 1.6 & 1.2 & 1.7 & 2.2 & 2.3 & 2.4 & 4.0 & 4.6 & 0.4 & 0.2 & 6.0 & 6.0 & 7.0 & 6.2 \\
\hline $\mathrm{Z} 238$ & 1.4 & 1.4 & 2.2 & 2.2 & 2.8 & 2.6 & 5.0 & 4.8 & 0.4 & 0.2 & 6.8 & 6.4 & 7.0 & 6.6 \\
\hline Mean & 1.3 & 1.6 & 2.0 & 2.0 & 2.1 & 2.0 & 4.2 & 4.0 & 0.3 & 0.2 & 5.8 & 5.9 & 6.3 & 6.4 \\
\hline $\mathrm{LSD}_{0.05}{ }^{2}$ & \multicolumn{2}{|c|}{0.2} & \multicolumn{2}{|c|}{0.1} & \multicolumn{2}{|c|}{0.2} & \multicolumn{2}{|c|}{0.1} & \multicolumn{2}{|c|}{0.1} & \multicolumn{2}{|c|}{0.2} & \multicolumn{2}{|c|}{0.3} \\
\hline $\operatorname{LSD}_{0.05}{ }^{y}$ & \multicolumn{2}{|c|}{0.2} & \multicolumn{2}{|c|}{0.2} & \multicolumn{2}{|c|}{0.3} & \multicolumn{2}{|c|}{0.2} & \multicolumn{2}{|c|}{0.1} & \multicolumn{2}{|c|}{0.2} & \multicolumn{2}{|c|}{0.4} \\
\hline
\end{tabular}

${ }_{\text {LSD }}$ for differences between cultivar means for the same $\mathrm{S}$ concentration.

$\mathrm{y}_{\mathrm{LSD}}$ for differences between cultivar means for the different $\mathrm{S}$ concentrations. 
Table 3. Correlation coefficients ( $r$ ) between bulb concentrations of several compounds associated with flavor in onions averaged across 16 short-day onion cultivars grown with high $\left(4.0 \mathrm{meq} \cdot \mathrm{liter}^{-1}\right)$ and low $S\left(0.1 \mathrm{meq} \cdot \mathrm{liter}^{-1}\right)$ fertility.

\begin{tabular}{|c|c|c|c|c|c|c|c|c|c|c|}
\hline Variable $^{z}$ & BPY & EPY & $S$ & SSC & DM & SUC & FRU & GLU & TRS & FT \\
\hline \multicolumn{11}{|c|}{ Correlation coefficients $(\mathbf{r})$} \\
\hline \multicolumn{11}{|c|}{4.0 meq S/liter } \\
\hline TPY & $0.41^{* *}$ & $0.91^{* *}$ & $0.01^{\mathrm{Ns}}$ & $0.11^{\mathrm{NS}}$ & $0.02^{\mathrm{NS}}$ & $-0.03^{\mathrm{NS}}$ & $-0.28^{\mathrm{NS}}$ & $0.31^{*}$ & $0.11^{\mathrm{Ns}}$ & $0.06^{\mathrm{NS}}$ \\
\hline BPY & --- & $-0.01^{\mathrm{Ns}}$ & $0.13^{\mathrm{NS}}$ & $-0.07^{\mathrm{NS}}$ & $-0.43^{* *}$ & $-0.02^{\mathrm{Ns}}$ & $-0.07^{\mathrm{Ns}}$ & $-0.15^{\mathrm{NS}}$ & $0.11^{\mathrm{NS}}$ & $-0.09^{\mathrm{NS}}$ \\
\hline EPY & & --- & $-0.05^{\mathrm{Ns}}$ & $0.14^{\mathrm{NS}}$ & $0.22^{\mathrm{NS}}$ & $-0.02^{\mathrm{NS}}$ & $-0.27^{\mathrm{Ns}}$ & $0.41^{* *}$ & $0.08^{\mathrm{NS}}$ & $-0.07^{\mathrm{NS}}$ \\
\hline S & & & --- & $-0.30^{*}$ & $-0.34^{*}$ & $-0.16^{\mathrm{NS}}$ & $-0.21^{\mathrm{Ns}}$ & $-0.05^{\mathrm{Ns}}$ & $0.01^{\mathrm{NS}}$ & $-0.07^{\mathrm{Ns}}$ \\
\hline SSC & & & & --- & $0.53^{* *}$ & $0.77^{* *}$ & $0.26^{*}$ & $0.42^{* *}$ & $0.26^{\mathrm{NS}}$ & $0.63^{* *}$ \\
\hline DM & & & & & --- & $0.43^{* *}$ & $0.21^{\mathrm{NS}}$ & $0.47^{* *}$ & $0.21^{\mathrm{NS}}$ & $0.47^{* *}$ \\
\hline SUC & & & & & & --- & $0.31^{*}$ & $0.14^{\mathrm{NS}}$ & $0.31^{*}$ & $0.54^{* *}$ \\
\hline FRU & & & & & & & -- & $0.09^{\mathrm{Ns}}$ & $0.71^{* *}$ & $0.10^{\mathrm{NS}}$ \\
\hline GLU & & & & & & & & --- & $0.76^{* *}$ & $0.38^{* *}$ \\
\hline TRS & & & & & & & & & -- & $0.33^{*}$ \\
\hline \multicolumn{11}{|c|}{0.1 meq S/liter } \\
\hline TPY & $0.55^{* *}$ & $0.78^{* *}$ & $0.25^{\text {NS }}$ & $0.05^{\mathrm{NS}}$ & $-0.02^{\mathrm{Ns}}$ & $0.08^{\mathrm{NS}}$ & -0.01 & $0.08^{\mathrm{Ns}}$ & $0.11^{\mathrm{NS}}$ & $0.46^{* *}$ \\
\hline BPY & -- & $-0.09^{\mathrm{Ns}}$ & $-0.08^{\mathrm{NS}}$ & $-0.10^{\mathrm{NS}}$ & $-0.03^{\mathrm{Ns}}$ & $-0.15^{\mathrm{NS}}$ & $-0.01^{\mathrm{NS}}$ & $0.43^{* *}$ & $0.11^{\mathrm{NS}}$ & $0.14^{\mathrm{NS}}$ \\
\hline EPY & & -- & $0.36^{* *}$ & $0.13^{\mathrm{Ns}}$ & $-0.01^{\mathrm{NS}}$ & $0.21^{\mathrm{NS}}$ & $-0.01^{\mathrm{NS}}$ & $-0.22^{\mathrm{NS}}$ & $0.09^{\mathrm{NS}}$ & $0.44^{* *}$ \\
\hline$S$ & & & -- & $-0.48^{* *}$ & $-0.69^{* *}$ & $-0.45^{* *}$ & $-0.10^{\mathrm{NS}}$ & $-0.40^{* *}$ & $0.01^{\mathrm{NS}}$ & $-0.12^{\mathrm{NS}}$ \\
\hline SSC & & & & $\cdots$ & $0.48^{* *}$ & $0.67^{* *}$ & $0.32^{*}$ & $0.32^{*}$ & $0.40^{* *}$ & $0.46^{* *}$ \\
\hline $\mathrm{DM}$ & & & & & -- & $0.57^{* *}$ & $0.23^{\mathrm{Ns}}$ & $0.29^{*}$ & $0.32^{*}$ & $0.41^{* *}$ \\
\hline SUC. & & & & & & --- & $0.07^{\mathrm{Ns}}$ & $-0.13^{\mathrm{Ns}}$ & $-0.05^{\mathrm{Ns}}$ & $0.49^{* *}$ \\
\hline FRU & & & & & & & --- & $0.31^{*}$ & $0.75^{* *}$ & $0.27^{\mathrm{NS}}$ \\
\hline GLU & & & & & & & & --- & $0.86^{* *}$ & $0.08^{\mathrm{Ns}}$ \\
\hline TRS & & & & & & & & & --- & $0.20^{\mathrm{NS}}$ \\
\hline
\end{tabular}

$\overline{{ }^{2} \text { Total pyruvic acid (TPY), background pyruvic acid (BPY), enzymatically formed pyruvic acid (EPY), sulfur (S), soluble solids (SSC), dry matter }}$ (DM), sucrose (SUC), fructose (FRU), glucose (GLU), total reducing sugars (TRS), and total fructans (FT).

However, 'Rio Ringo' had low bulb DM and low bulb S concentration with low S fertility and 'Maestro' had high bulb DM and high bulb S concentration with high-S fertility. WSC comprised up to $88 \%$ of DM in onions (Darbyshire and Henry, 1979). The association between bulb DM and EPY, in contrast, was poor and nonsignificant with both $\mathrm{S}$ fertility levels (Table 3 ).

Bulb sucrose ranged from 0.2 ('Granex 429') to $2.0 \mathrm{~g} / 100 \mathrm{~g} \mathrm{FW}$ ('Rio Rajirad') with high S fertility and from 0.9 ('Primavera') to $2.6 \mathrm{~g} / 100 \mathrm{~g} \mathrm{FW}$ ('Granex 429') with low-S (Table 2). Bulb fructose ranged from 1.3 ('Primavera') to $2.3 \mathrm{~g} / 100 \mathrm{~g}$ FW ('Sweet Vidalia' and 'Sweet Georgia') with high-S fertility and from 1.5 ('Gran Prix') to $2.4 \mathrm{~g} / 100 \mathrm{~g}$ FW ('Rio Rajirad' and 'Rio Bravo') with low S. Bulb glucose ranged from 1.9 ('Primavera', 'Special 38', and 'Rio Bravo') to $2.8 \mathrm{~g} / 100 \mathrm{~g}$ FW ('Z238') with high S and from 1.3 ('Gran Prix') to $2.8 \mathrm{~g} / 100 \mathrm{~g}$ FW ('Willmette Sweet') with low S. Bulb FT concentrations were low in all cultivars at both $S$ fertility levels. In general, low DM cultivars had high reducing sugar concentrations and low total fructan concentrations (Darbyshire and Henry, 1979; Randle, 1992a). Bulb FT ranged from 0.1 ('Primavera') to $0.6 \mathrm{~g} / 100 \mathrm{~g}$ FW ('Rio Rajirad') with high $\mathrm{S}$ fertility and from 0.1 ('Sweet Vidalia' and 'Rio Ringo') to $0.7 \mathrm{~g} /$ $100 \mathrm{~g}$ FW ('Rio Bravo') with low S. The correlation between bulb $\mathrm{S}$ concentration and all concentrations of individual carbohydrates with high $\mathrm{S}$ fertility, and between bulb $\mathrm{S}$ concentration and concentrations of fructose and FT with low S fertility were nonsignificant (Table 3). A poor but significant negative correlation was found between bulb $\mathrm{S}$ concentration and concentrations of sucrose $(r=-0.45 ")$ and glucose $(r=-0.40 * *)$ with low S. Correlations between bulb concentrations of EPY and individual carbohydrates were nonsignificant at both $\mathrm{S}$ fertility levels, except for glucose with high $\mathrm{S}\left(r=0.41^{* *}\right)$ and total fructans with low $\mathrm{S}\left(r=0.44^{* *}\right)$.

Our results have shown that significant variation of bulb con- centrations of WSC, S, and pungency existed among short-day onion cultivars bred for the "sweet" market. In addition, S fertility affected bulb WSC, S, and pungency. Poor correlations between bulb concentrations of S and the WSC measured, however, suggested that pungency and sweetness function independently in fresh-market short-day onion cultivars.

\section{Literature Cited}

Aylsworth, J.D. 1991. Sweet onion showdown. Amer. Veg. Grower 39(9):32-34.

Bajaj, K.L., G. Kaur, J. Singh, and S.P.S. Gill. 1980. Chemical evaluation of some important varieties of onion (Allium cepa L.). Qualitas Plant. Plant Foods Human Nutr. 30:117-122.

Balasubramonian, A.S., G.V. Gothandaraman, and K.K. Krishnamoorthy. 1978. Effect of sulphur application on the yield and quality of onion (Allium cepa L.). Agr. Res. J. Kerala. 17:138-140.

Bedford, L.V. 1984. Dry matter and pungency tests on British grown onions. J. Natl. Inst. Agr. Bot. 16:58-61.

Darbyshire, B. and R.J. Henry. 1979. The association of fructans with high percentage dry weight in onion cultivars suitable for dehydrating. J. Sci. Food Agr. 30:1035-1038.

Darbyshire, B. and B.T. Steer. 1990. Carbohydrate biochemistry, p. 1-6. In: H.D. Rabinowitch and J.L. Brewster (eds.). Onions and allied crops. vol. 3. CRC Press, Boca Raton, Fla.

Freeman, G.G. and N. Mossadeghi. 1970. Effect of sulphate nutrition on flavour components of onion (Allium cepa). J. Sci. Food Agr. 21:610-615. Freeman, G.G. and N. Mossadeghi. 1973. Studies on the relationship between water regime and flavour strength in water cress (Rorippa nasturium-aquaticum [L.] Hayek,) cabbage (Brassica oleracea var. capitata) and onion (Allium cepa). J. Hort. Sci. 48:365-378.

Freeman, G.G. and R.J. Whenham. 1975. A rapid spectrophotometric method of determination of thiopropanal S-oxide (lachrymator) in onion (Allium cepa L.) and its significance in flavor studies. J. Sci. Food Agr. 26:1529-1543. 
Gamiely, S., W.M. Randle, H.A. Mills, and D.A. Smittle. 1991. Onion plant growth, bulb quality, and water uptake following ammonium and nitrate nutrition. HortScience 26:1061-1063.

Hoagland, D.R. and D.I. Arnon. 1950. The water culture method for growing plants without soil. California Agr. Expt. Sta. Circ. 347.

Jones, J.B. and R.A. Isaac. 1972. Determination of sulfur in plant material using a Leco sulfur analyzer. J. Agr. Food Chem. 20:1292-1294.

Jones, H.A. and L.K. Mann. 1963. Onions and their allies: Botany, cultivation, and utilization. Interscience, New York.

Lancaster, J.E. and M.J. Boland. 1990. Flavor biochemistry, p. 33-72. In: H.D. Rabinowitch and J.L. Brewster (eds.). Onions and allied crops. vol. 3. CRC Press, Boca Raton, Fla.

Lancaster, J.E., P.F. Reay, J.D. Mann, W.D. Bennett, and J.R. Sedcole. 1988. Quality in New Zealand-grown onion bulbs-A survey of chemical and physical characteristics. N.Z. J. Expt. Agr. 16:279-285.

Paterson, D.R. 1979. Sulfur fertilization effects on onion yield and pungency. Texas Agr. Expt. Sta. Prog. Rpt. 3551.

Platenius, H. and J.E. Knott. 1941. Factors affecting onion pungency. J. Agr. Res. 62:371-379.
Randle, W.M. 1992a. Sulfur nutrition affects nonstructural water-soluble carbohydrates in onion germplasm. HortScience 27:52-55.

Randle, W.M. 1992b. Onion germplasm interacts with sulfur fertility for plant sulfur utilization and bulb pungency. Euphytica 59:151-156.

Randle, W.M. 1992c. Sampling procedures to estimate flavor potential in onion. HortScience 27: 1116-1117.

Schwimmer, S. and D.G. Guadagni. 1962. Relation between olfactory threshold concentration and pyruvic acid content of onion juice. J. Food Sci. 27:94-97.

Schwimmer, S. and W.J. Weston. 1961. Enzymatic development of pyruvic acid in onion as a measure of pungency. J. Agr. Food Chem. 9:301-304.

Smittle, D.A. 1984. Responses of onions to sulfur and nitrogen fertilization. Georgia Agr. Expt. Sta. Res. Rpt. 455.

Steel, R.G.D. and J.H. Torrie. 1980. Principles and procedures of statistics: A biometrical approach. McGraw-Hill, New York.

Vavrina, C.S. and D. Granberry. 1988. Dry bulb onions. Univ. Georgia Ext. Circ. 801.

Whitaker, J.R. 1976. Development of flavor, odor, and pungency in onion and garlic. Adv. Food Res. 22:73-133. 